\title{
Geobacillus gargensis sp. nov., a novel thermophile from a hot spring, and the reclassification of Bacillus vulcani as Geobacillus vulcani comb. nov.
}

Correspondence
Tamara N. Nazina
nazina@inmi.host.ru

\author{
Tamara N. Nazina, ${ }^{1}$ Elena V. Lebedeva, ${ }^{1}$ Andrei B. Poltaraus, ${ }^{2}$ \\ Tatyana P. Tourova, ${ }^{1}$ Alexandre A. Grigoryan, ${ }^{1}$ Diyana Sh. Sokolova, ${ }^{1}$ \\ Anatoliy M. Lysenko ${ }^{1}$ and George A. Osipov ${ }^{3}$ \\ ${ }^{1}$ Institute of Microbiology, Russian Academy of Sciences, pr. 60-letiya Oktyabrya 7/2, Moscow, \\ 117312 Russia \\ ${ }^{2}$ Engelhardt Institute of Molecular Biology, Russian Academy of Sciences, ul. Vavilova 32, \\ Moscow, 117984 Russia \\ ${ }^{3}$ Research Group of Academician Yu. Isakov, Russian Academy of Medical Sciences, \\ Sadovaya-Kudrinskaya 15, Moscow, 103001 Russia
}

Published online ahead of print on 30 April 2004 as DOI 10.1099/ ijs.0.02932-0.

The GenBank/EMBL/DDBJ accession number for the 16S rRNA gene sequence of Geobacillus gargensis $\mathrm{Ga}^{\top}$ is $\mathrm{AY} 193888$.

Electron micrographs showing the flagellation of strain $\mathrm{Ga}^{\top}$ and thin sections of vegetative cells of this strain are available as supplementary material in IJSEM Online. Data pertaining to the cellular fatty acid composition of strain $\mathrm{Ga}^{\top}$, and $\mathrm{G}+\mathrm{C}$ content and DNA-DNA hybridization values are also available in IJSEM Online.

\section{INTRODUCTION}

In 2001, thermophilic bacilli of phylogenetic group 5 (Ash et al., 1991) were classified in a new genus, Geobacillus (Nazina et al., 2001). The bacteria of this genus with growth temperatures ranging from 35 to $78{ }^{\circ} \mathrm{C}$ are widespread in various geographical areas on Earth (Claus \& Berkeley, 1986; White et al., 1993; Manachini et al., 2000; Markossian et al., 2000; Nazina et al., 2000, 2001; Maugeri et al., 2002). The genus includes the species Geobacillus stearothermophilus, Geobacillus thermocatenulatus, Geobacillus thermoleovorans, Geobacillus kaustophilus, Geobacillus thermoglucosidasius, 
Geobacillus thermodenitrificans, Geobacillus subterraneus, Geobacillus uzenensis, Geobacillus caldoxylosilyticus and Geobacillus toebii (Logan \& Berkeley, 1984; Claus \& Berkeley, 1986; Golovacheva et al., 1975; Suzuki et al., 1983; Priest et al., 1988; White et al., 1993; Zarilla \& Perry, 1987; Manachini et al., 2000; Ahmad et al., 2000; Nazina et al., 2001; Fortina et al., 2001a; Sung et al., 2002). Many thermophilic bacilli that have not yet been included in recognized species ('Bacillus caldolyticus', 'Bacillus caldotenax', 'Bacillus caldovelox' and 'Geobacillus uralicus'), and the recognized species Bacillus thermantarcticus, Saccharococcus thermophilus and Bacillus vulcani belong to genetic group 5, which is close to the genus Geobacillus both phenotypically and phylogenetically (Ash et al., 1991; Rainey et al., 1994; Caccamo et al., 2000; Heinen \& Heinen, 1972; Rainey \& Stackebrandt, 1993; Nystrand, 1984; Nicolaus et al., 1996; Popova et al., 2002). Members of the genus Geobacillus contain iso-branched saturated fatty acids (iso-C15:0, iso-C16:0 and iso-C17:0) as the major fatty acids and exhibit high intrageneric similarity of their 16S rRNA gene sequences (96-5-99·2 \%) (Nazina et al., 2001; Fortina et al., 2001a).

When studying the microbial communities of the Garga hot spring located in the north-eastern part of the Transbaikal region, we isolated several dominant aerobic, thermophilic, spore-forming bacteria in pure cultures. The Garga spring is characterized by a maximum temperature of $75^{\circ} \mathrm{C}$ and $\mathrm{pH} 7 \cdot 8-8 \cdot 5$. When the water temperature decreases to about $60^{\circ} \mathrm{C}$, the microbial mats that occur in this spring begin to develop. The colour of the mats varies from orange on the surface to green in deeper layers. The mats contain oxygenic cyanobacteria and non-oxygenic green filamentous photosynthetic bacteria, for example Chloroflexus (V. M. Gorlenko, personal communication). The material used for the isolation of bacilli was taken from the upper layer of a microbial mat. The preliminary phenotypic and genotypic characterization of one of the isolates ( $\operatorname{strain} \mathrm{Ga}^{\mathrm{T}}$ ) suggested its affiliation with the genus Geobacillus. In this study, we report the relevant characteristics of strain $\mathrm{Ga}^{\mathrm{T}}$ and the phenotypic and genotypic characteristics of the species B. vulcani (Caccamo et al., 2000), which allow strain $\mathrm{Ga}^{\mathrm{T}}$ to be classified as a novel species, Geobacillus gargensis sp. nov., and B. vulcani to be reclassified as Geobacillus vulcani comb. nov.

\section{METHODS}

Bacterial strains, maintenance and characterization. Strain $\mathrm{Ga}^{\mathrm{T}}$ was isolated from the upper layer of a microbial mat by using the technique of serial dilutions and inoculation of an agar medium containing sucrose (Adkins et al., 1992). The agar plates were incubated at $60{ }^{\circ} \mathrm{C}$. The colonies that grew within a few days were transferred to a liquid medium of the same composition. The purity of the isolate was tested microscopically.

Cell morphology, physiological characteristics, common DNA characteristics, 16S rRNA gene sequences, phylogenetic properties and cellular fatty acid profile were studied as described previously (Nazina et al., 2001).
The reference strains used in this study were obtained from the DSMZ (Deutsche Sammlung von Mikroorganismen und Zellkulturen) (G. uzenensis DSM $13551^{\mathrm{T}}$, G. subterraneus DSM $13552^{\mathrm{T}}$, Bacillus vulcani DSM $13174^{\mathrm{T}}$ and G. kaustophilus DSM $7263^{\mathrm{T}}$ ), from the AllRussian Collection of Microorganisms (G. uzenensis B-2228, ' $G$. uralicus' B-2276, G. thermocatenulatus $\mathrm{B}-1259^{\mathrm{T}}$ and Bacillus subtilis B-4537) and from Christian Jeanthon (Laboratory of Marine Microbiology, Station Biologique, CNRS UPR9042, Roscoff, France) (G. stearothermophilus DSM $22^{\mathrm{T}}$, G. thermoleovorans DSM $5366^{\mathrm{T}}$ and G. thermodenitrificans DSM 466).

\section{RESULTS AND DISCUSSION}

The morphological and chemical characteristics of strain $\mathrm{Ga}^{\mathrm{T}}$ are consistent with its affiliation with the genus Geobacillus. Strain $\mathrm{Ga}^{\mathrm{T}}$ produced small, round, mucous, small, non-pigmented colonies with a diameter of about $1 \mathrm{~mm}$. Vegetative cells were motile (in the exponential phase) peritrichously flagellated rods with rounded ends (Fig. A, available as supplementary material in IJSEM Online). The cells were $1 \cdot 0-1 \cdot 5 \mu \mathrm{m}$ wide and $6-12 \mu \mathrm{m}$ long. The endospore was terminal and ellipse-shaped, and slightly distended the mother cell. Cell division was usually symmetric. The electron microscopic examination of cells showed that they are likely to be Gram-positive (Fig. B, available as supplementary material in IJSEM Online), since their cell wall did not have the external lipoprotein layer. The Gram-positive staining of the cell wall was also demonstrated by light microscopy. The cell wall had a complex structure, namely, it was composed of three to five layers. The outermost layer exhibited the presence of regularly arranged structures that are typical of S layers. The immature spores located within the sporangium contained the cytoplasm, polyribosomes, the coat and the cortex.

The physiological characteristics of strain $\mathrm{Ga}^{\mathrm{T}}$ are given in Table 1 and in the species description. Strain $\mathrm{Ga}^{\mathrm{T}}$ was found to be a thermophilic bacterium, since it could grow within the temperature range $45-70{ }^{\circ} \mathrm{C}$, with an optimum growth temperature of $60-65^{\circ} \mathrm{C}$. The isolate grew well within the $\mathrm{pH}$ range $5 \cdot 5-8 \cdot 5$, with an optimum $\mathrm{pH}$ for growth of $6 \cdot 5-7 \cdot 0$. The isolate was able to utilize a variety of sugars, carboxylic acids and hydrocarbons aerobically. The bacterium was able to grow in synthetic media and did not require any growth factors, vitamins, $\mathrm{NaCl}$ or $\mathrm{KCl}$. Significant culture turbidity was observed in a medium with sucrose as the sole carbon and energy source, with the generation time being $2 \cdot 5 \mathrm{~h}$.

\section{5 rRNA gene sequence analysis}

The analysis of the almost-complete 16S rRNA gene sequence (1459 nucleotides) of strain $\mathrm{Ga}^{\mathrm{T}}$, corresponding to Escherichia coli positions (Brosius et al., 1978) 37-1479, showed that this strain has sequence similarity values of $94 \cdot 6-99 \cdot 3 \%$ to the recognized species of the genus Geobacillus (Fig. 1). The strain formed a separate phylogenetic cluster, which was closely related to G. kaustophilus (99.3\% sequence similarity), G. thermoleovorans $(99 \cdot 1 \%$ similarity), G. thermocatenulatus ( $99 \cdot 0 \%$ similarity) and 
Table 1. Characteristics that differentiate Geobacillus gargensis sp. nov. from the closely related species of the genus Geobacillus

Taxa: 1, G. gargensis strain $\mathrm{Ga}^{\mathrm{T}}$; 2, G. stearothermophilus; 3, G. thermocatenulatus; 4, G. thermoglucosidasius; 5, G. thermoleovorans; 6, G. kaustophilus; 7, G. thermodenitrificans; 8, G. uzenensis; 9, G. subterraneus; 10, G. caldoxylosilyticus; 11, G. toebii; 12, G. vulcani. Symbols: +, growth/activity observed; -, no growth/activity observed; W, weak growth; ND, not determined; V, variable within group. Data are from the present study (G. gargensis) or from Logan \& Berkeley (1984), Claus \& Berkeley (1986) and Priest et al. (1988) (G. stearothermophilus); Golovacheva et al. (1975), Nazina et al. (2001) and data from the present study (G. thermocatenulatus); Suzuki et al. (1983) (G. thermoglucosidasius); Zarilla \& Perry (1987) and Nazina et al. (2001) (G. thermoleovorans); Priest et al. (1988) and White et al. (1993) (G. kaustophilus); Manachini et al. (2000) (G. thermodenitrificans); Nazina et al. (2001) (G. uzenensis; G. subterraneus); Ahmad et al. (2000) and Fortina et al. (2001a) (G. caldoxylosilyticus); Sung et al. (2002) (G. toebii); Caccamo et al. (2000) and data from the present study (B. vulcani=G. vulcani). Strain $\mathrm{Ga}^{\mathrm{T}}$ and all other strains are negative for indole production and are catalase-positive, and produce acid from glucose, fructose, maltose, mannose, sucrose and trehalose (in the description of G. toebii, most of these characteristics are absent).

\begin{tabular}{|c|c|c|c|c|c|c|c|c|c|c|c|c|}
\hline Characteristic & 1 & 2 & 3 & 4 & 5 & 6 & 7 & 8 & 9 & 10 & 11 & 12 \\
\hline Cell length $(\mu \mathrm{m})$ & $6 \cdot 0-12$ & $2-3 \cdot 5$ & $6-8$ & $3-7$ & $3 \cdot 5$ & $\leqslant 0 \cdot 9$ & $1 \cdot 5-2 \cdot 5$ & $4 \cdot 7-8 \cdot 5$ & $4 \cdot 6-8 \cdot 0$ & $4-6$ & $2 \cdot 0-3 \cdot 5$ & $4 \cdot 0-7 \cdot 0$ \\
\hline \multicolumn{13}{|l|}{ Production of acid from: } \\
\hline Adonitol & - & $\mathrm{V}$ & $-{ }^{\star}$ & - & $\mathrm{V}$ & + & $\mathrm{ND}$ & - & - & $\mathrm{ND}$ & - & $-*$ \\
\hline L-Arabinose & - & - & - & - & - & - & + & + & - & + & - & $-{ }^{*}$ \\
\hline Galactose & + & - & + & - & + & $\mathrm{V}$ & + & + & + & + & - & + \\
\hline Glycerol & + & + & + & + & $\mathrm{V}$ & - & + & + & + & + & - & + \\
\hline Inositol & - & - & - & - & - & + & $\mathrm{ND}$ & - & - & $\mathrm{ND}$ & + & $-*$ \\
\hline Lactose & - & - & - & - & - & - & + & - & - & + & - & + \\
\hline Mannitol & + & $\mathrm{V}$ & + & + & + & + & & + & $\mathrm{ND}$ & + & - & - \\
\hline Rhamnose & - & - & - & + & - & - & $\mathrm{V}$ & - & - & $\mathrm{V}$ & - & $-*$ \\
\hline \multicolumn{13}{|l|}{ Hydrolysis of: } \\
\hline Aesculin & + & $\mathrm{V}$ & $+^{*}$ & + & $\mathrm{ND}$ & - & ND & + & + & ND & - & + \\
\hline Casein & + & $\mathrm{V}$ & $\mathrm{W}$ & + & + & + & $\mathrm{v}$ & - & - & + & + & - \\
\hline Gelatin & - & + & - & - & - & + & $\mathrm{ND}$ & + & - & ND & - & + \\
\hline Starch & + & + & $+^{*}$ & + & + & + & $\mathrm{V}$ & + & + & + & - & + \\
\hline \multicolumn{13}{|l|}{ Utilization of: } \\
\hline n-Alkanes & + & + & + & ND & + & ND & + & + & + & ND & + & $+^{*}$ \\
\hline Formate & - & - & $-{ }^{*}$ & ND & $\mathrm{ND}$ & $\mathrm{V}$ & ND & - & + & ND & - & $-*$ \\
\hline Acetate & + & $\mathrm{V}$ & $+^{*}$ & ND & + & - & ND & + & + & ND & - & $-*$ \\
\hline Lactate & + & - & $+^{*}$ & ND & ND & - & ND & + & + & $\mathrm{w}$ & - & $-*$ \\
\hline Citrate (Simmons) & - & $\mathrm{V}$ & + & - & + & + & $\mathrm{V}$ & - & - & $\mathrm{V}$ & - & + \\
\hline $\mathrm{pH}$ range & $5 \cdot 5-8 \cdot 5$ & $6 \cdot 0-8 \cdot 0$ & ND & $6 \cdot 5-8 \cdot 5$ & $6 \cdot 2-7 \cdot 5$ & $6-8$ & $6-8$ & $6 \cdot 2-7 \cdot 8$ & $6 \cdot 0-7 \cdot 6$ & $6 \cdot 8-7 \cdot 2$ & $6 \cdot 0-9 \cdot 0$ & $5 \cdot 5-9 \cdot 0$ \\
\hline Temperature range $\left({ }^{\circ} \mathrm{C}\right)$ & $45-70$ & $37-65$ & $35-78$ & $42-69$ & $45-70$ & $37-68$ & $45-70$ & $45-65$ & $45-70$ & $42-70$ & $45-70$ & $37-72$ \\
\hline $\begin{array}{l}\text { DNA G }+C \text { content } \\
\quad(\operatorname{mol} \%)\left(T_{\mathrm{m}}\right)\end{array}$ & $52 \cdot 9$ & $46-52$ & $55 \cdot 2$ & $45-46$ & $52-58$ & $51-55$ & $48 \cdot 2-52 \cdot 3$ & $50 \cdot 4-51 \cdot 5$ & $49 \cdot 7-52 \cdot 3$ & $44-50 \cdot 2$ & $43 \cdot 9 \dagger$ & $53 \cdot 0$ \\
\hline
\end{tabular}

${ }^{\star}$ Data from the present study.

$\dagger$ Determined by HPLC. 


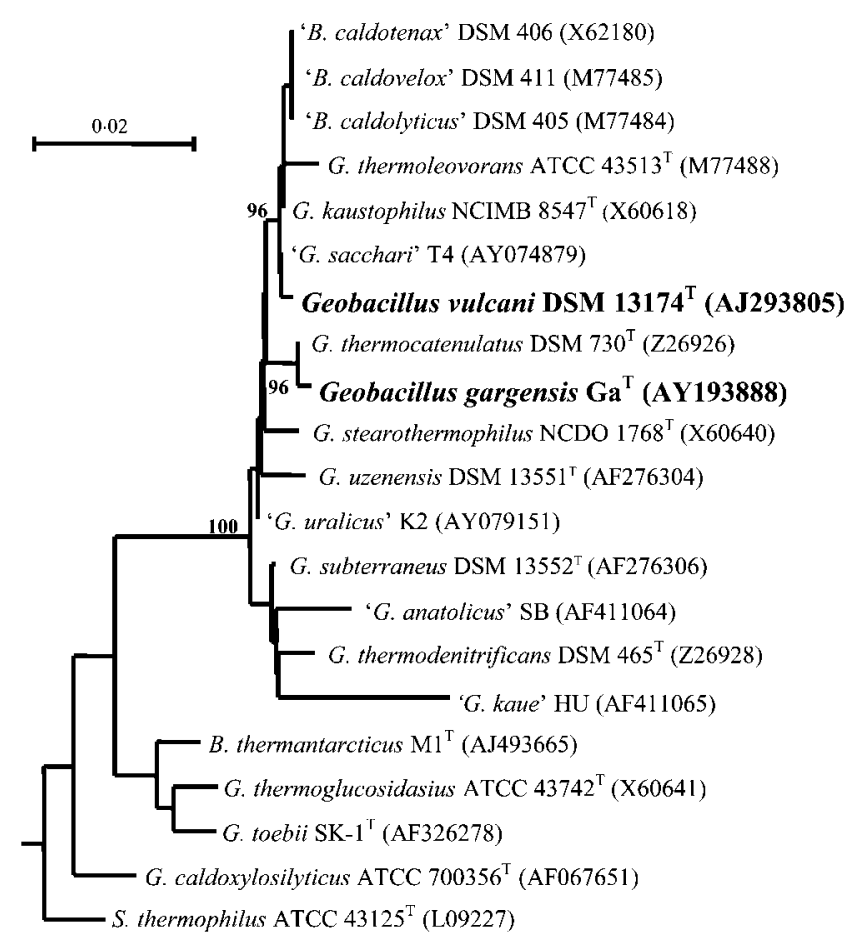

Fig. 1. Phylogenetic tree showing the positions of strain $\mathrm{Ga}^{\top}$ and B. vulcani among Geobacillus species. The scale bar represents the expected number of changes per sequence position (the Jukes-Cantor distance). Bootstrap values (expressed as percentage of 100 replications) are shown at branch points; values greater than $95 \%$ were considered significant. G., Geobacillus; B., Bacillus; S., Saccharococcus. The GenBank/EMBL/DDBJ accession numbers of the reference strains are shown in parentheses.

B. vulcani ( $98 \cdot 8 \%$ similarity). The analysis also showed that B. vulcani was closely related to G. kaustophilus $(99 \cdot 4 \%$ sequence similarity). The phylogenetic clustering of $B$. vulcani with members of the genus Geobacillus, with $95 \cdot 3-99 \cdot 4 \%$ sequence similarity values, suggested that $B$. vulcani may actually represent a species of the genus Geobacillus. In order to verify the taxonomic positions of strain $\mathrm{Ga}^{\mathrm{T}}$ and B. vulcani DSM $13174^{\mathrm{T}}$, they were subjected to DNA-DNA hybridization analysis with the type strains of most of the known Geobacillus species.

\section{DNA base composition and DNA-DNA similarity}

The $\mathrm{G}+\mathrm{C}$ content of the DNA of strain $\mathrm{Ga}^{\mathrm{T}}$ was found to be $52 \cdot 9 \pm 0 \cdot 2 \mathrm{~mol} \%$. The DNA-DNA reassociation values of strain $\mathrm{Ga}^{\mathrm{T}}$ with $B$. vulcani $\mathrm{DSM} 13174^{\mathrm{T}}$ and the nine type or reference strains of the genus Geobacillus varied from 31 to $55 \%$ (see Table A available in IJSEM Online). These values are within the range that is typical of a genospecies (30-70\%) (Wayne et al., 1987). The DNA-DNA reassociation values indicate that both strain $\mathrm{Ga}^{\mathrm{T}}$ and $B$. vulcani DSM $13174^{\mathrm{T}}$ belong to the genus Geobacillus as separate species. The DNA-DNA hybridization values between the thermophilic Geobacillus strains and a mesophilic strain of B. subtilis, taken as an outgroup, varied from 3 to $10 \%$.

Our earlier (Nazina et al., 2001) and present data contradict the results of the hybridization experiments of Sunna et al. (1997), who reported a very high value of DNA-DNA reassociation (more than $75 \%$ ) between Bacillus thermocatenulatus, Bacillus kaustophilus and Bacillus thermoleovorans. This disagreement may be due to the absence of adequate hybridization controls at inter- and intraspecies levels in the experiments of Sunna et al. (1997). The DNADNA reassociation values obtained by Caccamo et al. (2000) for B. kaustophilus, Bacillus thermodenitrificans and Bacillus stearothermophilus were within a range of $40 \cdot 4-61 \cdot 4 \%$, which is in agreement with our data.

\section{Fatty acids}

The fatty acid profile of strain $\mathrm{Ga}^{\mathrm{T}}$ (see Table $\mathrm{B}$ and Fig. C in IJSEM Online) was largely composed of iso-C15:0 $(25 \cdot 84 \%)$, iso-C16:0 (25.91\%) and iso-C17:0 (19.79\%). In the fatty acid composition, strain $\mathrm{Ga}^{\mathrm{T}}$ and the bacterium B. vulcani were clustered with the species of the genus Geobacillus, but not with the thermophilic species of the genera Bacillus and Ureibacillus or Thermobacillus and Aneurinibacillus (data not shown) (Kämpfer, 1994; Nazina et al., 2001; Manachini et al., 2000; Ahmad et al., 2000; Fortina et al., 2001a, b; Caccamo et al., 2000; Andersson et al., 1995).

Strain $\mathrm{Ga}^{\mathrm{T}}$ differed both genotypically and phenotypically from the recognized species of the genus Geobacillus. The strain utilized acetate and lactate, but not citrate, and hydrolysed casein and aesculin, but not gelatin. The strain was also able to produce acids from glycerol and ribose, but not from inositol, lactose or xylose. The methyl red and the urea decomposition tests were negative. All these properties allowed us to differentiate strain $\mathrm{Ga}^{\mathrm{T}}$ from B. vulcani and the representatives of the genus Geobacillus. Based on the results of the phenotypic and genotypic analyses, we conclude that strain $\mathrm{Ga}^{\mathrm{T}}$ is a member of a novel Geobacillus species, for which we propose the name Geobacillus gargensis sp. nov.

\section{Characteristics of reference strains}

The phenotypic characteristics of B. vulcani DSM $13174^{\mathrm{T}}$ and G. thermocatenulatus $\mathrm{B}-1259^{\mathrm{T}}$, additional to those available in the original description of these strains, are summarized in Table 1. The results of the Voges-Proskauer test and the test for the anaerobic growth of strain DSM $13174^{\mathrm{T}}$ in glucose broth were negative (as with the other species of the genus Geobacillus). Strain DSM $13174^{\mathrm{T}}$ grew on $\mathrm{C}_{6}$ hydrocarbons, but not on $\mathrm{C}_{14}-\mathrm{C}_{16}$ hydrocarbons; no acids were produced from adonitol, arabinose, inositol, rhamnose or sorbitol. In contrast to their original descriptions (Golovacheva et al., 1975; Caccamo et al., 2000), strain B- $1259^{\mathrm{T}}$ hydrolysed starch, whereas strain DSM $13174^{\mathrm{T}}$ was catalase-positive. A comparison of B. vulcani DSM $13174^{\mathrm{T}}$ with the phylogenetically closest species G. kaustophilus 
DSM $7263^{\mathrm{T}}(99 \cdot 4 \%$ sequence similarity) indicated that they differ phenotypically in the ability to hydrolyse casein and to produce acids from glycerol, inositol, lactose and ribose. Thus, the species B. vulcani must be reclassified as Geobacillus vulcani comb. nov. on the basis of its physiological characteristics, phylogenetic position and DNA-DNA reassociation values.

\section{Description of Geobacillus gargensis sp. nov.}

Geobacillus gargensis [gar.g.en'sis. N.L. adj. gargensis of Garga, pertaining to the Garga hot spring located in Eastern Siberia (Russia), from which the type strain was isolated].

Cells are rod-shaped, motile by means of peritrichous flagella and produce terminally located ellipsoidal spores in slightly swollen sporangia. The cells are $1 \cdot 0-1 \cdot 5 \mu \mathrm{m}$ wide and 6-12 $\mu \mathrm{m}$ long. Gram-positive, with the chemoorganotrophic type of metabolism. Aerobic. No acids are produced from raffinose. Utilizes hydrocarbons $\left(\mathrm{C}_{12}-\mathrm{C}_{16}\right)$, butyrate, pyruvate, fumarate, succinate, peptone, tryptone, nutrient broth, potato agar and yeast extract as carbon and energy sources. No growth occurs on methanol, ethanol, propanol, butanol or isobutanol. Unable to grow autotrophically on $\mathrm{H}_{2}+\mathrm{CO}_{2}$. Unable to produce $\mathrm{NH}_{3}$ from peptone. $\mathrm{H}_{2} \mathrm{~S}$ is not produced. The egg-yolk lecithinase test is negative. Growth factors, vitamins, $\mathrm{NaCl}$ and $\mathrm{KCl}$ are not required for growth. The optimum temperature for growth is $60-65{ }^{\circ} \mathrm{C}$, with an optimum $\mathrm{pH}$ of $6 \cdot 5-7 \cdot 0$. Fatty acid profile consists of iso-C15:0 (25.84\%), iso-C16:0 $(25 \cdot 91 \%)$, iso-C17:0 (19.79\%), anteiso-C17:0 (8.2\%), anteiso-C15:0 (1.99\%), C17:1 (4.21\%), iso-C17:1 $(3 \cdot 91 \%)$ and iso-C18:0 (1.40\%). Carbon source utilization and hydrolysis of chromogenic substrates (including differentiating characters for all Geobacillus species) are indicated in Table 1.

The type strain is $\mathrm{Ga}^{\mathrm{T}}\left(=\mathrm{VKM} \mathrm{B}-2300^{\mathrm{T}}=\mathrm{DSM} 15378^{\mathrm{T}}\right)$. Isolated from the Garga hot spring.

\section{Description of Geobacillus vulcani comb. nov.}

Basonym Bacillus vulcani Caccamo et al. 2000.

Geobacillus vulcani (vul.ca'ni. L. gen. m. n. vulcani of the volcano, pertaining to the Aeolian Island volcano with a shallow marine hydrothermal vent, from which the organism was isolated).

Phylogenetic and chemotaxonomic data indicate that Bacillus vulcani is more closely related to species of the genus Geobacillus than to any species of the genus Bacillus. The cultural, morphological and physiological characteristics of the species, described by Caccamo et al. (2000), are valid, except that strain DSM $13174^{\mathrm{T}}$ is catalase-positive. Fatty acid profile consists of iso-C15:0 (16.6\%), iso-C16:0 $(14 \cdot 6 \%)$, iso-C17:0 (21\%), anteiso-C17:0 (11.4\%) and C18:0 (13\%). Carbon source utilization and hydrolysis of chromogenic substrates are indicated in Table 1.
The type strain is $3 \mathrm{~s}-1^{\mathrm{T}}\left(=\mathrm{DSM} 13174^{\mathrm{T}}=\mathrm{CIP} 106305^{\mathrm{T}}\right)$. Isolated from sediment of a shallow hydrothermal vent.

\section{ACKNOWLEDGEMENTS}

We are grateful to V. Gorlenko from the Institute of Microbiology, Russian Academy of Sciences, Moscow, Russia for providing samples from the Garga hot spring and to L. L. Mityushina from INMI RAS for assistance. This work was supported by grants from the Russian Foundation for Basic Research (project numbers 01-04-49250, 02-0439002) and from the Russian Ministry of Science and Technology (project no. 43.073.1.1.2515).

\section{REFERENCES}

Adkins, J. P., Cornell, L. A. \& Tanner, R. S. (1992). Microbial composition of carbonate petroleum reservoir fluids. Geomicrobiol J 10, 87-97.

Ahmad, S., Scopes, R. K., Rees, G. N. \& Patel, B. K. C. (2000). Saccharococcus caldoxylosilyticus sp. nov., an obligately thermophilic, xylose-utilizing, endospore-forming bacterium. Int J Syst Evol Microbiol 50, 517-523.

Andersson, M., Laukkanen, M., Nurmiaho-Lassila, E.-L., Rainey, F. A., Niemelä, S. I. \& Salkinoja-Salonen, M. (1995). Bacillus thermosphaericus sp. nov., a new thermophilic ureolytic bacillus isolated from air. Syst Appl Microbiol 18, 203-220.

Ash, C., Farrow, A. E., Wallbanks, S. \& Collins, M. D. (1991). Phylogenetic heterogeneity of the genus Bacillus revealed by comparative analysis of small-subunit-ribosomal RNA sequences. Lett Appl Microbiol 13, 202-206.

Brosius, J., Palmer, M. L., Kennedy, P. J. \& Noller, H. F. (1978). Complete nucleotide sequence of a $16 \mathrm{~S}$ ribosomal RNA gene from Escherichia coli. Proc Natl Acad Sci U S A 75, 4801-4805.

Caccamo, D., Gugliandolo, C., Stackebrandt, E. \& Maugeri, T. L. (2000). Bacillus vulcani sp. nov., a novel thermophilic species isolated from a shallow marine hydrothermal vent. Int J Syst Evol Microbiol 50, 2009-2012.

Claus, D. \& Berkeley, R. C. W. (1986). Genus Bacillus Cohn 1872. In Bergey's Manual of Systematic Bacteriology, vol. 2, pp. 1105-1139. Edited by P. H. A. Sneath, N. S. Mair, M. E. Sharpe \& J. G. Holt. Baltimore: Williams \& Wilkins.

Fortina, M. G., Mora, D., Schumann, P., Parini, C., Manachini, P. L. \& Stackebrandt, E. (2001a). Reclassification of Saccharococcus caldoxylosilyticus as Geobacillus caldoxylosilyticus (Ahmad et al. 2000) comb. nov. Int J Syst Evol Microbiol 51, 2063-2071.

Fortina, M. G., Pukall, R., Schumann, P., Mora, D., Parini, C., Manachini, P. L. \& Stackebrandt, E. (2001b). Ureibacillus gen. nov., a new genus to accommodate Bacillus thermosphaericus (Andersson et al. 1995), emendation of Ureibacillus thermosphaericus and description of Ureibacillus terrenus sp. nov. Int J Syst Evol Microbiol 51, 447-455.

Golovacheva, R. S., Loginova, L. G., Salikhov, T. A., Kolesnikov, A. A. \& Zaitseva, G. N. (1975). A new thermophilic species Bacillus thermocatenulatus nov. sp. Microbiology (English translation of Mikrobiologiya) 44, 230-233.

Heinen, U. J. \& Heinen, W. (1972). Characteristics and properties of a caldo-active bacterium producing extracellular enzymes and two related strains. Arch Microbiol 82, 1-23.

Kämpfer, P. (1994). Limits and possibilities of total fatty acid analysis for classification and identification of Bacillus species. Syst Appl Microbiol 17, 86-98. 
Logan, N. A. \& Berkeley, R. C. W. (1984). Identification of Bacillus strains using the API system. J Gen Microbiol 130, 1871-1882.

Manachini, P. L., Mora, D., Nicastro, G., Parini, C., Stackebrandt, E., Pukall, R. \& Fortina, M. G. (2000). Bacillus thermodenitrificans sp. nov., nom. rev. Int J Syst Evol Microbiol 50, 1331-1337.

Markossian, S., Becker, P., Märkl, H. \& Antranikian, G. (2000). Isolation and characterization of lipid-degrading Bacillus thermoleovorans IHI-91 from an icelandic hot spring. Extremophiles 4, 365-371.

Maugeri, T. L., Gugliandolo, C., Caccamo, D. \& Stackebrandt, E. (2002). Three novel halotolerant and thermophilic Geobacillus strains from shallow marine vents. Syst Appl Microbiol 25, 450-455.

Nazina, T. N., Tourova, T. P., Poltaraus, A. B., Novikova, E. V., Ivanova, A. E., Grigoryan, A. A., Lysenko, A. M. \& Belyaev, S. S. (2000). Physiological and phylogenetic diversity of the thermophilic spore-forming hydrocarbon-oxidizing bacteria from oil fields. Microbiology (English translation of Mikrobiologiya) 69, 96-102.

Nazina, T. N., Tourova, T. P., Poltaraus, A. B. \& 8 other authors (2001). Taxonomic study of aerobic thermophilic bacilli: descriptions of Geobacillus subterraneus gen. nov., sp. nov. and Geobacillus uzenensis sp. nov. from petroleum reservoirs and transfer of Bacillus stearothermophilus, Bacillus thermocatenulatus, Bacillus thermoleovorans, Bacillus kaustophilus, Bacillus thermoglucosidasius and Bacillus thermodenitrificans to Geobacillus as the new combinations G. stearothermophilus, G. thermocatenulatus, G. thermoleovorans, G. kaustophilus, G. thermoglucosidasius and G. thermodenitrificans. Int J Syst Evol Microbiol 51, 433-446.

Nicolaus, B., Lama, L., Esposito, E., Manca, M. C., di Prisco, G. \& Gambacorta, A. (1996). "Bacillus thermoantarcticus" sp. nov., from Mount Melbourne, Antarctica: a novel thermophilic species. Polar Biol 16, 101-104.

Nystrand, R. (1984). Saccharococcus thermophilus gen. nov., sp. nov. isolated from beet sugar extraction. Syst Appl Microbiol 5, 204-219.
Popova, N. A., Nikolaev Yu, A., Tourova, T. P., Lysenko, A. M., Osipov, G. A., Verkhovtseva, N. V. \& Panikov, N. S. (2002). Geobacillus uralicus, a new species of thermophilic bacteria. Microbiology (English translation of Mikrobiologiya) 71, 335-341.

Priest, F. G., Goodfellow, M. \& Todd, C. (1988). A numerical classification of the genus Bacillus. J Gen Microbiol 134, 1847-1882.

Rainey, F. A. \& Stackebrandt, E. (1993). Phylogenetic evidence for the relationship of Saccharococcus thermophilus to Bacillus stearothermophilus. Syst Appl Microbiol 16, 224-226.

Rainey, F. A., Fritze, D. \& Stackebrandt, E. (1994). The phylogenetic diversity of thermophilic members of the genus Bacillus as revealed by $16 \mathrm{~S}$ rDNA analysis. FEMS Microbiol Lett 115, 205-211.

Sung, M.-H., Kim, H., Bae, J.-W. \& 9 other authors (2002). Geobacillus toebii sp. nov., a novel thermophilic bacterium isolated from hay compost. Int J Syst Evol Microbiol 52, 2251-2255.

Sunna, A., Tokajian, S., Burghardt, J., Rainey, F., Antranikian, G. \& Hashwa, F. (1997). Identification of Bacillus kaustophilus, Bacillus thermocatenulatus and Bacillus strain HSP as members of Bacillus thermoleovorans. Syst Appl Microbiol 20, 232-237.

Suzuki, Y., Kishigami, T., Inoue, K., Mizoguchi, Y., Eto, N., Takagi, M. \& Abe, S. (1983). Bacillus thermoglucosidasius sp. nov., a new species of obligately thermophilic bacilli. Syst Appl Microbiol 4, 487-495.

Wayne, L. G., Brenner, D. J., Colwell, R. R. \& 9 other authors (1987). International Committee on Systematic Bacteriology. Report of the ad hoc committee on reconciliation of approaches to bacterial systematics. Int J Syst Bacteriol 37, 463-464.

White, D., Sharp, R. J. \& Priest, F. G. (1993). A polyphasic taxonomic study of thermophilic bacilli from a wide geographical area. Antonie Leeuwenhoek 64, 357-386.

Zarilla, K. A. \& Perry, J. J. (1987). Bacillus thermoleovorans, sp. nov., a species of obligately thermophilic hydrocarbon utilizing endosporeforming bacteria. Syst Appl Microbiol 9, 258-264. 